\title{
A expropriação da previdência pública como estratégia de financeirização do capital
}

\author{
The expropriation of public social security \\ as a strategy from capital financialization
}

\author{
Júlio César Lopes de Jesus \\ Mestre em Sociologia pela Universidade Federal de Sergipe-UFS, doutorando em \\ Política Social pela Universidade de Brasília-UnB, DF, Brasil, assistente social no Instituto \\ Nacional do Seguro Social-INSS em Sergipe, Brasil. lopesdejesus25@yahoo.com.br
}

Resumo: A financeirização da economia, no contexto da reestruturação produtiva e de redefinição das orientações macroeconômicas e funções do Estado social, vem ocasionando sérias consequências às populações mundiais, particularmente em relação aos direitos e políticas sociais destinados à classe trabalhadora. Em meio a essa estratégia, a Previdência Social tem sido uma das mais atacadas, representando um risco constante à proteção social dos trabalhadores e suas famílias no Brasil e no mundo.

Palavras-chave: Financeirização. Acumulação capitalista. Política social. Previdência Social. Brasil.
Abstract: The financialization of the economy, in the context of productive restructuring and a redefinition of macroeconomic guidelines and functions of the Social State, bringing serious consequences for the world population, particularly in relation of rights e social policy for the working class. Through this strategy, social security has been one of the most attacked, representing a constant risk for the social protection of workers and their families in Brazil and in all over the world.

Keywords: Financialization. Capitalist accumulation. Social policy. Social security. Brazil.

\section{Introdução}

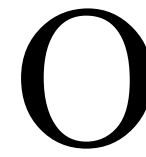

presente artigo analisa algumas das particularidades contemporâneas da ofensiva do capital contra a classe trabalhadora brasileira e seus direitos, particularmente a partir de uma sistemática tentativa de desmonte das políticas sociais, com destaque para a política de Previdência Social. Tais ataques vêm sendo favorecidos pelo Estado 
social ${ }^{1}$ brasileiro, tendo como objetivo propiciar a retomada da recomposição de taxas ascendentes de lucro e a intensificação da acumulação capitalista, a partir da financeirização da economia como uma das características modernas do capital e suas estratégias de lucratividade.

Nestas análises, recorre-se à tradição marxista, na qual se entende que o método em Marx conduz a uma compreensão mais profunda e crítica acerca das particularidades da Previdência Social brasileira, enquanto uma política social forjada num país de capitalismo periférico-dependente, que expressa suas contradições, despertando múltiplos e conflitantes interesses entre classes fundamentais antagônicas e que vem servindo, ao mesmo tempo, tanto aos interesses do capital quanto aos do trabalho (sendo este último cada vez menos atendido). Cada vez mais o Estado social capitalista se constitui num espaço fundamental e privilegiado para a materialização das contradições e disputas pela direção estratégica e hegemônica das políticas sociais e de seus recursos na sociedade capitalista, tendo clara opção para o favorecimento da acumulação, aumentando a sua aproximação com aquilo que Marx e Engels (2005, p. 42) denominaram de "comitê para gerir os negócios comuns de toda a classe burguesa".

Neste contexto, a financeirização do capital vem ganhando cada vez mais espaço na agenda do capitalismo internacional e seus organismos, como forma estratégica de superar os limites da acumulação capitalista — os quais dependiam, essencialmente, do ciclo de produção, consumo, distribuição e troca de mercadorias - para uma nova fase, na qual o capital parasitário-financeiro ganha contornos hegemônicos, tendo nítida repercussão, com

1. A utilização de alguns termos que designam o novo padrão de intervenção estatal, observado a partir dos anos 1930 até início dos anos 1970, a exemplo de Estado de Bem-Estar Social (Welfare State) ou Estado Providência (État Providence), merece alguma atenção. Essas formulações, conforme analisa Boschetti (2016), representaram determinadas particularidades territoriais e históricas encontradas em seus países de origem. A autora vem defendendo, desde os anos 1990, o recurso à categoria "Estado social" para demarcar a função estatal na regulação das relações econômicas e sociais no capitalismo, sem que se atribua ingenuamente a este Estado - pelo recurso ao "social" — uma característica "anticapitalista" ou de "socializador de riquezas", tendo na implementação das políticas sociais uma determinação central de suas funções. Realiza ainda algumas considerações importantes sobre a utilização da categoria Estado social, razão pela qual também se adota essa categoria neste artigo. 
maior ou menor intensidade, em todos os países do mundo, sejam os de capitalismo central sejam os de capitalismo periférico-dependente. Dentre esses alvos privilegiados para o projeto de financeirização e acumulação capitalista encontra-se a Previdência Social. Em 2015, somente em juros (R \$ 502 bilhões), o Brasil gastou mais do que com a Previdência (R \$ 486 bilhões), segundo dados da Anfip (2017).

\section{A reestruturação capitalista, 0 redirecionamento da intervenção estatal e os ataques aos direitos e às políticas sociais}

O capital, enquanto relação social resultante das sociabilidades desenvolvidas na e pela ordem burguesa, "é uma relação natural, universal e eterna" (Marx, 2011b, p. 57). Ou seja, o capital representa o resultado do modo de produção capitalista e que adquire um significado mais complexo do que o encontrado em suas formas embrionárias, pré-capitalistas, a partir de sua generalização na sociedade capitalista. Este significado fica mais evidente no momento em que as contribuições trazidas por Marx e por autores que, como ele, dedicaram-se aos estudos da sociedade burguesa e suas particularidades, revelam as complexas e contraditórias relações que envolvem as forças produtivas, a força de trabalho, os meios de produção, a obtenção da mais-valia, a divisão e exploração de classes. Todas essas particularidades do processo de produção capitalista passam a ser representadas em sua forma imediata, no ciclo D-M-D', aprofundado por Marx em $O$ capital (2013), a partir de sua "crítica à economia política". Marx analisa e expõe com propriedade como o dinheiro (D) pode se transformar em capital (D'), sendo esse processo de conversão de "dinheiro" em "capital" atravessado por relações sociais de produção capitalista, com emprego da força de trabalho, das forças produtivas, da exploração e obtenção da mais-valia, da transformação do dinheiro em mercadoria (M) e da mercadoria em mais dinheiro (capital), realimentando esse ciclo. A relação estudada em profundidade por Marx diz respeito a um modo de produção específico, num sistema político-econômico historicamente determinado, 
dentro de relações sociais que envolvem outras relações sociais, imersas em totalidades de totalidades mais complexas.

Para Mandel (1985), que analisou a natureza das crises capitalistas através de suas relações de produção, entender a "mercadoria" na relação "mercadoria" e "dinheiro" e, ao mesmo tempo, enquanto produto do trabalho privado e do trabalho social, é de fundamental importância para compreender os fundamentos das crises do capital. Neste caso, a mercadoria não possui o reconhecimento imediato do trabalho social contido nela, pois, para isso, ela dependerá de sua "venda" e do "preço" pelo qual será vendida. Dessa forma, a produção da mais-valia, em si — ou seja, a relação de exploração da força de trabalho do proletário - não é condição suficiente para a sua realização. Isto, por si só, não garantirá a existência da mais-valia. É preciso consumá-la, realizá-la a partir de sua venda. É preciso que ocorra o desmembramento entre mercadoria e dinheiro e, em seguida, a realização do seu valor de troca, numa relação que envolve "valor de uso" e "valor de troca", para que se chegue ao momento das crises de superprodução. ${ }^{2}$ Ainda segundo Mandel, enquanto as crises pré-capitalistas eram tipicamente de "subprodução de valores de uso", as crises capitalistas se caracterizam pela "superprodução de valores de troca". Assim,

Não é porque há muitos poucos produtos que a vida econômica se desregula. É porque há a impossibilidade de venda de mercadorias a preços que garantam o lucro médio — isto é, porque há, portanto, "muitas mercadorias" — que a vida econômica se desorganiza, que as fábricas fecham as suas portas, que os patrões demitem e que a produção, as rendas, as vendas, os investimentos e o emprego caem. (Mandel, 1985, p. 210)

É esse "círculo vicioso" da produção capitalista e de suas relações sociais que engendrarão as condições necessárias para a sua própria disfunção,

2. Em Mandel (1985), as crises de superprodução ocorrem quando há uma conjugação de fatores, a exemplo da superacumulação de capitais, o subconsumo de massas, a anarquia da produção, a desproporcionalidade e a queda da taxa de lucro. 
para o surgimento das crises cíclicas do capital. Uma crise ocasionada pela indissociabilidade entre o subconsumo de massas (oferta de mercadorias acima da procura e possibilidade de consumo) e a superacumulação (lucros não alcançados em condições satisfatórias e suficientes para propiciar a expansão de bens de capital), conforme defendido por Mandel (1990). Não de outra forma, o próprio Marx defende que o capitalismo, em si, "engendra os meios materiais de sua própria destruição" (2013, p. 831; grifos meus). E para salvaguardar as crises do capital, o Estado social passou a ter um papel estratégico e fundamental na fase do capitalismo tardio, ${ }^{3}$ nos países de capitalismo central, tanto na estrutura quanto na superestrutura, ao passo que Mandel (1985) vai dizer que o Estado passará a agir enquanto "capitalista total ideal", na medida em que passa a ampliar as suas funções nas relações sociais capitalistas, de forma que será impensável a existência da produção e reprodução capitalista sem a atuação direta do Estado nesses processos. Esta, para Mandel, será a principal função do Estado capitalista.

Com isso, as funções do Estado social, que haviam sido significativamente ampliadas em todas as esferas e dimensões das sociabilidades no capitalismo tardio (cultura, educação, trabalho, assistência etc.), por força da crise de 1929 e, principalmente, após a Segunda Guerra Mundial (Mandel, 1985), passam a ser redirecionadas, particularmente e, num primeiro momento, nos países do capitalismo central. Esse período de crise mundial, situado entre as décadas de 1970 e 1980, será classificado por Mandel como de "ondas longas" com tendência à estagnação, caracterizando-se pela

3. Este é um conceito mandeliano que, em vários momentos, aparece em algumas literaturas no Brasil com um sentido oposto e, por isso mesmo, equivocado em relação ao que Mandel pretendeu expressar. É possível que isso tenha sido resultado de uma tradução equivocada do termo empregado por Mandel. "Capitalismo tardio", neste caso, não significa uma espécie de "capitalismo atrasado", que "chegou depois" ou "pouco desenvolvido" - e que, nesse sentido, mais estaria servindo para designar os países de capitalismo periférico do que os países de capitalismo central —, mas sim um capitalismo "maduro", de países que atingiram o ápice do desenvolvimento de suas forças produtivas, a exemplo da Inglaterra e da França.

4. É oportuno perceber que há certa resistência de alguns autores em aceitar a teoria de "ondas longas" da crise do capital, a exemplo de Mészáros (2011), que identifica nessa ideia de Mandel uma "hipótese explicativa um tanto misteriosa [e que], foi injetada de forma apologética em debates mais recentes" (Mészáros, 2011, p. 41; grifos do autor). Ainda segundo o autor húngaro, o que estaria acontecendo com o sistema capitalista 
combinação de uma fase de recessão (mais longa e mais profunda), com fases de retomada e boom de crescimento econômico mais curtas e menos expansivas (Mandel, 1985).

Em meio ao cenário de crise, os direitos passam a ser sistematicamente atacados e ressignificados enquanto "privilégios abomináveis" e que precisavam ser rapidamente abolidos, em nome da responsabilidade fiscal e da boa governabilidade das ações do Estado. O que se viu após isso foi a emergência de governos nos chamados "países de capitalismo avançado" (Harvey, 2014a) que representavam os interesses desse novo padrão político-econômico, a exemplo da ascensão de Thatcher (1979) na Inglaterra e de Reagan (1980) nos Estados Unidos. Esses governos promoveram um profundo e sistemático ataque aos direitos dos trabalhadores em seus respectivos países, intensificando a flexibilização e a precarização das relações de trabalho (subcontratação, emprego temporário, parcial e atividades autônomas etc.) e um aprofundamento dos aspectos constitutivos da financeirização do capital, que se espalharam por todo o mundo capitalista (Chesnais, 2012; Harvey, 2014a).

Deste modo, uma das formas encontradas pelos capitalistas para recuperar as suas taxas ascendentes de lucro, principalmente em territórios de países capitalistas dependentes, foi a estratégia imperialista (Fontes, 2010; Harvey, 2014a e b). Os alvos passam a ser as nações dependentes. Harvey, em sua teoria da "produção de uma economia do espaço", afirma que as atividades capitalistas passam a produzir desenvolvimento geográfico desigual, a partir do momento que o capitalista opta por explorar locais onde os custos sejam menores e/ou a taxa de lucro seja maior, a partir de isenções e renúncias fiscais, promovidas pelo Estado social capitalista, no qual a mão de obra seja barata na região, uma boa localização para escoamento da produção, matéria-prima mais barata (Harvey, 2014b), atraindo, dessa forma, o interesse de capitais internacionais circulantes para esses territórios. Mais que isso, na

não nos permitiria pensar apenas nas tradicionais crises cíclicas do capital, mas, de forma mais plausível (superando-se aí quaisquer formas de otimismo), as próprias tendências de estagnação, dos limites estruturais do capital, seu ponto de colapso (Mészáros, 2011). 
busca por formas alternativas e mais vantajosas de promover a acumulação capitalista, Fontes (2010) observa que

as formidáveis contradições do capital-imperialismo vinham à tona, explicitando as disputas internas, através de sucessivos golpes, demonstrativos da exasperação do impulso expropriador avassalador do capital sob o predomínio monetário e do crescimento das tensões internas entre os países capital-imperialistas. Toda a formidável escalada da acumulação e da concentração de capitais decorrera da arquitetura elaborada em função da Guerra Fria, já ultrapassada na prática. Envolvia uma crescente interconexão dos processos de produção, reforçando os elos entre os países interimperialistas e entre eles e os demais, sempre assimétrica em favor dos Estados Unidos e jamais homogênea ou estável. As lideranças políticas e econômicas do país preponderante, os Estados Unidos, passaram a atuar em direções contraditórias, procurando assenhorear-se totalmente do processo e, ao mesmo tempo, aprofundar a integração desigual das forças produtivas, através da plena circulação internacional de capitais. (Fontes, 2010, p. 192-193; grifos da autora)

Conforme analisa Fontes, o capital monetário vai ganhando cada vez mais espaço, destruindo fronteiras e barreiras que o impediam, tempos atrás, de se dilatar pelo mundo, havendo certo abandono das prioridades de investimentos, outrora maciços, na transformação capitalista clássica da matéria-prima em mercadoria, para promover o fetichismo da mercadoria em capital monetário, o qual "vê como produtivas todas as atividades remuneratórias e, portanto, certamente expande tanto a exploração do trabalho, as expropriações, quanto a especulação e o capital fictício" (Fontes, 2010, p. 202). Na nova lógica do capital-imperialista e sua vertente financeirista, o próprio capitalista, detentor do dinheiro (D), a relação D-d-M-d'-D' já não o interessa mais. O resultado que realmente importa é este: D-D' (dinheiro emprestado volta como dinheiro e lucro, em forma de juros). Esse é o ponto de vista dele, o que realmente o interessa. A ele não interessa os processos internos (d-M-d') que geraram essa relação/resultado final. Isso representa apenas tempo que medeia entre o empréstimo (D) e o retorno (D'). 
Dessa forma, Fontes (2010) conclui sobre o capitalista financista que "a atividade especifica da extração de sobretrabalho não lhe diz respeito. Seu problema é assegurar a venda do capital monetário, tendo como contrapartida sua reprodução ampliada" (Idem, p. 25; grifos da autora). É possível compreender que os interesses de investimentos no setor produtivo e na indústria dão lugar aos investimentos em áreas de grande atração do setor especulativo-financeirista (juros, títulos públicos, ações, seguros, fundos de pensão, Bolsa de Valores etc.), no qual os bancos passam a ter importância estratégica para o desenvolvimento do capital monetário. Contudo, vem de Fontes (2010) a própria advertência aos capitalistas monetaristas em relação às consequências que o desinteresse pela relação de exploração, produção e reprodução da mais-valia pode vir a acarretar na acumulação capitalista, baseada apenas na financeirização da economia. Segundo a autora, "O sonho dourado D-D' depende da transfusão permanente que resulta da atividade da força de trabalho, concatenada por d-m-d"' (Idem, p. 30). Neste caso e, de alguma forma, a relação d-m-d' interfere diretamente para que D (dinheiro) transforme-se em D' (mais dinheiro).

Nessa crescente relação de financeirização da economia e de capitais monetaristas em escala mundial, Harvey também destaca que,

Esse "espantoso" mundo das altas finanças envolve uma variedade igualmente espantosa de atividades entrelaçadas, em que os bancos tomam maciços empréstimos de curto prazo uns dos outros, as companhias de seguro e fundos de pensão reúnem tal quantidade de fundos de investimento que terminam por funcionar como "formadores de mercado" dominantes, enquanto o capital industrial, mercantil e imobiliário se integram de tal maneira às estruturas e operações financeiras que se torna cada vez mais difícil dizer onde começam os interesses comerciais e industriais e terminam os interesses estritamente financeiros. (Harvey, 2014a, p. 154)

Mas pensar a expansão imperialista do capital monetário e da intensificação da financeirização da economia mundial apenas por meio dos próprios capitalistas ou pelas organizações internacionais que representam 
os seus interesses (Banco Mundial, FMI, Bird etc.) não seria possível sem a participação direta e crucial de um agente capitalista determinante para a concretização deste processo: o Estado social. Com a crise econômica, intensificada nos anos 1970 e com a estratégia imperialista adotada por grande parte dos países capitalistas centrais, estabelecer critérios mínimos e "parcerias" internacionais entre governos e que resultassem em cenários oportunos e favoráveis para a expansão da acumulação capitalista nos países de capitalismo periférico tornou-se imperativo para que o capital pudesse recuperar suas taxas ascendentes de lucro.

O Estado social capitalista continua tendo um papel fundamental, enquanto capitalista total ideal, para propiciar essa acumulação e favorecer os sistemas de crédito e as demais relações capitalistas especulativas, o que Behring vai chamar de "instrumentos de 'domesticação' do capitalismo" (Behring, 2003, p. 37). Passa-se então a reconhecer que: "As instituições estatais e financeiras detêm o poder-chave de gerar e oferecer crédito. Elas criam, com efeito, aquilo que se poderia denominar 'capital fictício' (ativos em títulos ou notas promissórias desprovidos de suporte material, mas que podem ser usados como dinheiro)" (Harvey, 2014b, p. 97).

Nessa sanha da expansão imperialista, por exemplo, Harvey descortina as estratégias adotadas pelos EUA para manter a liderança global do capital, através da utilização de seus bancos, dos mecanismos de endividamento dos países, tornando-os reféns do Fundo Monetário Internacional (FMI) e de Wall Street, forçando a abertura de mercados para os fluxos de capital financeiro $\mathrm{e}$, inclusive, a aderirem ao receituário neoliberal das reformas conservadoras (Harvey, 2014b). ${ }^{5}$ Tudo isso se utilizando de um belo e "humanitário" discurso, como os que recorrentemente foram proferidos por George W.

5. Não são poucas as vezes que os donos do capital se despiram de sua pele de cordeiro e mostram o lobo que se escondia sob ela. De fato, quando se trata de preservar os interesses da acumulação capitalista e livrar-se dos perigos que a ameacem, são diretos em seus "recados", a exemplo do episódio lembrado por Harvey (2014b) na ocasião da primeira eleição de Lula à presidência, em 2002 (derrotando o candidato José Serra, clara opção do capitalismo internacional), em que o representante do governo norte-americano de Bush, Robert Zoellick, teria dito que se Lula não seguisse os planos (ou seja, "lesse na cartilha") dos EUA para a efetivação do livre mercado nas Américas, teria que "exportar para a Antártica". 
Bush, nos quais, em sua prática imperialista, ao invadir outros países, após o fatídico 11 de setembro de 2001, afirmara que estaria levando "paz", "democracia" e "desenvolvimento" para superar a pobreza e as desigualdades nesses países, através do "libertário" livre-comércio e do livre mercado. Assim, ironicamente, Harvey afirma que os EUA levarão essa "dádiva” da liberdade (de mercado) para o mundo inteiro, quer ele queira ou não (Idem).

$\mathrm{Na}$ mesma linha de raciocínio desenvolvida por Harvey, verificamos que Cuba, acusada pelos sucessivos governos norte-americanos de ser uma "ditadura", curiosamente nunca tenha sido alvo das asas libertadoras dos EUA. Talvez a resposta para essa dúvida esteja no fato de os terríveis e sanguinários "ditadores" cubanos não terem em seu território os "desprezíveis" recursos petrolíferos encontrados nas "ditaduras" do Oriente Médio. Sobre a ação imperialista dos países do capitalismo central e seus reais interesses em relação aos países de capitalismo dependente, Mészáros (2011, p. 86) também apresenta as suas críticas,

Com certeza, nunca teve o sentido de satisfazer as necessidades da população faminta e socialmente carente dos países envolvidos, mas a de prover escoadouros irrestritos para a exportação de capital e gerar nos primeiros tempos níveis inimagináveis de superlucro, sob a ideologia da "modernização" e a eliminação do "subdesenvolvimento" [...]. Apesar de todo um discurso unilateral sobre "dependência", para não mencionar o discurso obscenamente hipócrita da "ajuda ao desenvolvimento", o capital ocidental tornou-se muito mais dependente do "Terceiro Mundo" - de matérias-primas, energia, mercados de capital e superlucros avidamente repatriados — do que o contrário.

É no próprio mercado de trabalho que se identifica uma "radical reestruturação", conforme aponta Harvey (2014a). O autor classifica dois grupos de trabalhadores nesse cenário: um primeiro que ele chama de "centro" e um segundo que chama de "periferia". O primeiro grupo, segundo Harvey, diminui a cada dia em todo o mundo e é formado por aqueles trabalhadores que ainda mantêm alguns direitos e benefícios, com algum nível de segurança no emprego, trabalho em tempo integral, previdência etc. Nesse primeiro grupo 
descrito por Harvey é possível identificarmos tipicamente os funcionários públicos. Já no segundo, o autor afirma que se encontram os trabalhadores mais precarizados da atualidade e que tem sido o grupo que mais cresce no mundo. Ele divide esse grupo em dois subgrupos, ambos precarizados, mas, o primeiro grupo periférico apresenta algum nível de emprego em tempo integral, enquanto o segundo convive com empregos com "tempo parcial, empregados casuais, pessoal com contrato por tempo determinado, temporários, subcontratação" (Idem, p. 144).

O que Harvey observa no que se refere à precarização e à flexibilização do trabalho e seus resultados, ou seja, na alta do desemprego, na informalidade do trabalho, na perda de benefícios, baixos salários, a partir das tendências abertas no início dos anos 1970, Marx também já analisava em “A lei geral da acumulação capitalista". Marx (2013) compreendeu que, em determinada fase do capitalismo, a produtividade do trabalho se daria não mais pela incorporação cada vez maior de contingentes de trabalhadores (superpopulação relativa) à parte variável do capital, mas sim pelo desenvolvimento das forças produtivas. A produtividade do trabalho passa, então, a ser alcançada a partir da diminuição da massa de trabalho e inversamente ao aumento de investimentos nos componentes do capital constante, aumentando, dessa forma, as fileiras do exército industrial de reserva, o qual possui importância central para o próprio desenvolvimento do sistema capitalista, conforme aponta Marx,

Mas se uma população trabalhadora excedente é um produto necessário da acumulação ou do desenvolvimento da riqueza com base capitalista, essa superpopulação se converte, em contrapartida, em alavanca da acumulação capitalista. Ela constitui um exército industrial de reserva disponível, que pertence ao capital de maneira tão absoluta como se ele o tivesse criado por sua própria conta. (Marx, 2013, p. 707)

Assim, identifica-se o quanto os trabalhadores passam a ser penalizados em suas garantias fundamentais, no campo do trabalho, a partir dos sistemáticos ataques que a lógica do sistema capitalista vem promovendo 
sob suas conquistas. A crise capitalista, nesse sentido, aparece como um elemento a mais no processo de dinamização do capital, criando novas condições que, claramente, visam recompor a acumulação capitalista e as formas de acumulação do capital, tendo nos trabalhadores e seus direitos os alvos preferenciais de sua ofensiva. No sistema capitalista os trabalhadores oscilaram entre conquistas importantes e derrotas dilacerantes no conjunto de seus direitos, mas, em todo esse período, o capital nunca saiu perdendo. A acumulação capitalista foi "garantida" em todos os momentos, ${ }^{6}$ tendo o Estado social como o seu principal fiador.

\section{A Previdência Social pública no Brasil como alvo da financeirização}

Dentre os principais direitos e políticas sociais que foram implementados ao longo dos séculos XIX e XX, a Previdência Social é, sem dúvida, o que tem despertado maior interesse por parte do sistema capitalista internacional, com maior destaque e intensidade a partir da crise mundial de 1970. A Previdência, em função de sua natureza, possui uma capacidade arrecadatória de volumes gigantescos de capitais, sendo isso a longo prazo (30, 35, 40 anos ou mais), o que aumenta sobremaneira o desejo dos capitalistas de se apropriar desses recursos bilionários. ${ }^{7}$

6. Vale lembrar que, mesmo nos momentos históricos nos quais houve avanços na constituição de leis e benefícios que puderam simbolizar alguma conquista e proporcionar ganhos para a classe trabalhadora, nos quais houve certo recuo na intensificação da exploração da mais-valia, o capital nunca deixou de ter garantidas as condições para sua plena efetividade e expansão. Ao contrário, o capital conseguiu manter, a exemplo do ocorrido no período do modelo keynesiano-fordista, com a criação de políticas sociais e de medidas de proteção social do trabalho, taxas sustentáveis de lucros ascendentes. Na própria composição do "salário", Marx identifica que a valorização destes, a partir de algum nível de aumento, apenas representa a “diminuição do trabalho não pago", em que a valorização dos salários poderá ocorrer desde que não ameace a própria acumulação capitalista. " $\mathrm{O}$ aumento do preço do trabalho é confinado, portanto, dentro dos limites que não só deixam intactos os fundamentos do sistema capitalista, mas asseguram sua reprodução em escala cada vez maior" (Marx, 2013, p. 697).

7. Conforme já indicamos anteriormente nos dados da Auditoria Cidadã da Dívida (2015), referentes ao orçamento da União de 2014, a Previdência Social constitui o gasto público nacional de maior volume 
No Brasil, com a promulgação da Constituição Federal de 1988, a Previdência Social, juntamente com as políticas de saúde e assistência social, passa a ser uma política de "seguridade social" e a contar com uma base de financiamento definida e "inovadora", conforme nos detalha Silva (2012). Ainda segundo a autora, "esse formato de financiamento permaneceu praticamente estável, apesar de mudanças introduzidas pela EC $n^{\circ} 20$, aprovada em 1998" (p. 181; grifos da autora). A partir da diversificada, progressiva e inovadora base de financiamento da Seguridade Social, prevista na Constituição Federal de 1988, pode-se afirmar que, desde então, a Previdência Social alcançou a condição de sustentabilidade de seu custeio, não sendo possível falar em "déficit" da Previdência Social, como a todo o momento o sistema financeiro e seus principais representantes, inclusive membros dos governos do país, têm buscado convencer os trabalhadores.

Com uma fonte tão grandiosa e de longo prazo de recursos públicos, não há espanto em se observar que as sucessivas manobras dos governos, alinhados com as orientações macroeconômicas do grande capital, buscam se apropriar, por diversas formas e vezes, dos recursos do fundo público, especialmente no que diz respeito à Previdência. Aliás, esta tem sido uma estratégia recorrente da acumulação capitalista para garantir as suas taxas de lucro, tendo a financeirização da economia como uma de suas principais manobras, como destaca Salvador (2010, p. 606),

A financeirização da riqueza implica em pressão sobre a política social, especialmente as instituições da seguridade social, pois aí está o nicho dos produtos financeiros. Com isso, as propostas neoliberais incluem a transferência da proteção social do âmbito do Estado para o mercado, a liberalização financeira passa pela privatização dos benefícios da seguridade social. (Salvador, 2010, p. 606)

A transformação da política social em "produto financeiro" e a mercantilização dos direitos e benefícios da Previdência Social vêm alimentando

\footnotetext{
financeiro, estimado em cerca de 472 bilhões (21,76\%), perdendo apenas para os recursos destinados para o pagamento de juros e amortização da dívida pública, que abocanha $45,11 \%$ do orçamento total.
} 
as tendências de financeirização e especulação econômicas, a partir das aposentadorias e pensões dos trabalhadores. Seu principal alvo passa a ser um fundo público altamente rentável e, por isso mesmo, muito cobiçado pelos setores rentistas da economia nacional e internacional, de modo que a orientação macroeconômica reinante passa a ser a da contratação de tais serviços e benefícios junto ao "mercado", por meio de contribuições particulares e através de bancos (particularmente os privados), e não mais através do Estado social, sob a forma de direitos de seguridade social, garantidas pelo Estado, como expresso na Constituição de 1988.

Essas orientações macroeconômicas que, no Brasil, foram seguidas rigorosamente a partir da década de 1990, tinham e têm como principal intenção fazer com que o Estado social brasileiro transfira para o "mercado" - "mecanismo maravilhoso" e que deveria ser o responsável pela "coordenação da economia", segundo o pensamento "social-liberal" à época (Behring, 2003) - a responsabilidade pela gestão do fundo público da Previdência Social. Assim, à reforma administrativa do Estado e ao recurso às privatizações, juntava-se também a proposta de "reforma"» da Previdência pública brasileira.

Boschetti (2016) relembra algumas das "orientações" do Banco Mundial para os países capitalistas, mencionando três dessas prescrições, dentre as quais a primeira delas é alvo de maior interesse por parte deste artigo. Consiste na redução dos sistemas públicos de previdência (Boschetti, 2016, p. 123). Essa redução dar-se-ia por meio do fim de alguns direitos, redução e restrição de outros, a exemplo da elevação das idades e definição de um teto para aposentadorias. Tais medidas possuem como principal intenção diminuir a atratividade da Previdência Social pública e incentivar o mercado dos planos privados de previdência (fundos de pensão fechados), retirando

8. É importante destacar aqui as considerações feitas por Behring (2003) acerca da utilização do termo "reforma". Para a autora, esse termo, conforme vem sendo recorrentemente utilizado no Brasil, constitui-se numa "apropriação indébita e fortemente ideológica da ideia reformista, a qual destituída de seu conteúdo progressista e submetida ao uso pragmático, como se qualquer mudança significasse uma reforma, não importando seu sentido, suas consequências sociais e direção sociopolítica" (Behring, 2003, p. 128; grifos meus). 
ou reduzindo, por parte do Estado Social, o controle do fundo público e proporcionando ao mercado um nicho grandioso para promover a acumulação capitalista. Dessa forma, analisa Boschetti (2016, p. 136-137),

\begin{abstract}
Os processos privatizantes, diretos e indiretos, da previdência e saúde púbicas, somados à supressão dos direitos do trabalho, se submetem ao imperativo da acumulação e, ao expropriar os direitos conquistados, suprimem dos trabalhadores a possibilidade de acessar parte da riqueza socialmente produzida, apropriada pelo Estado sob forma de fundo público constituído por impostos e tributos para financiar os serviços públicos. A supressão ou restrição de direitos existentes reduz a participação social do Estado na reprodução ampliada da força de trabalho [...] e, em novo contexto e condições históricas, deixa os trabalhadores "livres como pássaros", o que os impele a se submeter a não importa que tipo de trabalho ou atividade para assegurar sua subsistência e de sua família, ou seja, os lança ao jugo das relações de mercado sem proteção.
\end{abstract}

Sobre isto, observa-se que tanto o governo FHC quanto os governos de Lula e Dilma elegeram a previdência pública como uma das principais vilãs do falacioso déficit público e do desequilíbrio fiscal das contas do país, o que vem servindo de munição para aprofundar as contrarreformas da Previdência nesses governos, valendo-se do discurso de sustentabilidade do sistema. Em particular, sobre as orientações dos governos petistas, tem-se que a contrarreforma da Previdência dos servidores públicos federais, operada por Lula em 2003, bem como a aprovação do Fundo de Previdência Complementar dos servidores públicos federal (Funpresp), em 2012, e da edição da Medida Provisória n ${ }^{\circ}$ 664/2014 (convertida na Lei ${ }^{\circ}$ 13.135/2015) pelo governo Dilma Rousseff, consubstanciam-se na continuidade do movimento contrarreformista. Reafirmam-se os compromissos desses governos com o perverso projeto neoliberal, com a mundialização do capital, a desregulamentação do mercado e a fragilização da cobertura previdenciária, contrapondo-se à perspectiva de universalização de direitos (Silva, 2012). Assim, reedita-se aqui a afirmação feita por Marx de que os grandes fatos e personagens históricos se repetem ao menos duas vezes na vida, sendo da primeira vez como "tragédia" e da segunda vez como "farsa" (Marx, 
2011a). A "tragédia" neoliberal, que eclode mundialmente a partir da crise econômica de 1973 e que se aprofunda nos países latino-americanos entre as décadas de 1980 e 1990 (principalmente nesta última década) dá lugar a uma "farsa" neodesenvolvimentista, ${ }^{9}$ que tenta combinar um pseudocrescimento econômico sustentável associado ao combate das desigualdades sociais, através da hipertrofia da política de assistência social, ocorrida a partir dos anos 2000 .

Destaca-se ainda outro grande vilão das políticas sociais e dos trabalhadores brasileiros, o chamado "superávit primário", criado pelo governo FHC e mantido por Lula e Dilma, constituindo-se num esforço gigantesco para pagar a dívida pública, à custa do sangue e suor da classe trabalhadora brasileira e do sacrifício do financiamento das políticas sociais. Alimenta o superávit primário a famigerada Desvinculação das Receitas da União (DRU), que permite que até $20 \%{ }^{10}$ das receitas do Orçamento da União possam ser "redirecionados" para outra finalidade. Chama a atenção ainda o fato de que a DRU é uma das responsáveis por gerar o caos ideológico do falso déficit da Previdência Social, o qual, reiteradas vezes, já foi provado ser inexistente, conforme estudos realizados pela Anfip (Behring, 2008 e Silva, 2012).

Parece-nos oportuna a afirmação feita por Fontes: “Jamais o parasitismo de uma classe inteira foi tão evidente e provavelmente jamais uma classe inteira devotou-se de maneira tão sistemática e científica a aprofundar as formas de extração de mais-valia" (Fontes, 2010, p. 201; grifos meus). Aliás, vem de Fontes uma tese pertinente. Segundo a autora, ao tratar sobre as constantes formas de exploração e retiradas de direitos da classe trabalhadora, a "acumulação primitiva", conforme tratada por Marx, não se constitui em algo estanque, que ocorreu apenas no período inicial do capitalismo, mas sim em algo que vem ocorrendo ainda hoje, a partir das expropriações

9. Para uma melhor compreensão acerca do conceito "neodesenvolvimentista" e suas principais características, recomendamos o importante trabalho de Mota, Amaral e Peruzzo (2012).

10. A sangria para o conjunto da classe trabalhadora e para o financiamento das políticas sociais tende a ser ainda mais dramática a partir da recente aprovação da Proposta de Emenda à Constituição (PEC) nº 31/2016, que prorroga a DRU até 2023 e amplia sua voracidade percentual dos atuais $20 \%$ para $30 \%$. 
que ocorrem diariamente - mesmo que sob diferentes formas, mas com os mesmos fundamentos - , atingindo milhões de trabalhadores pelo mundo. Para ela, "as expropriações constituem um processo permanente, condição da constituição e expansão da base social capitalista e que, longe de se estabilizar, aprofunda-se e generaliza-se com a expansão capitalista" (Idem, p. 45). Esta, por sua vez, constitui-se numa tese que não está livre de polêmicas, como lembra Boschetti (2016, p. 127).

Sobre a expropriação dos direitos à Previdência Social, Fontes (2010) analisa que, a partir da ofensiva neoliberal, a justificativa de inviabilização das finanças públicas em manter as aposentadorias passa a constituir-se numa grande ameaça a todos os aposentados e trabalhadores ativos, a partir da reafirmação de que não se pode conceber que os trabalhadores se aposentem "tão novos". Dessa forma, passa-se a defender a elevação da idade mínima para a aposentadoria como algo "justo" e "necessário". Todavia, mesmo tendo sido feitas as "reformas", elevando-se significativamente a idade para se ter direito a aposentadoria e para que não se gastasse alguns "milhões" com os trabalhadores, de forma bastante contraditória, como lembra a autora, os governos buscaram salvar o sistema financeiro (bancos), em 2008, com alguns "trilhões" de dólares (Fontes, 2010). Assim, em relação à expropriação da classe trabalhadora, a partir dos seus direitos previdenciários,

O tema das expropriações se liga diretamente, porém, à concentração e à centralização: tratava-se de capturar recursos crescentes, de origem salarial, e de convertê-los em capital. Realizava-se um duplo movimento, de ameaça diante das aposentadorias e do estímulo às agências privadas de previdência (fundos de pensão e similares), entidades convertidas em gestoras não bancárias de capital portador de juros e de seu complemento, o capital fictício. (Fontes, 2010, p. 58)

O cenário apresentado atualmente, na realidade internacional e brasileira, demonstra que o capital, seus donos e representantes têm procurado formas sistemáticas de garantir a obtenção da mais-valia, particularmente a partir da 
estratégia de financeirização da economia, por meio de relações econômicas que se baseiam na especulação, nos juros, nas diversas maneiras de obter rápido retorno financeiro com o menor dispêndio possível de investimento de capital e tempo. Isto passa a se materializar a partir da intensificação da exploração e precarização da força de trabalho, seja a partir da redução de salários e benefícios - com a substituição de trabalhadores do centro pelos da periferia (Harvey, 2014b) —, seja pelo aumento da jornada de trabalho (como a proposta apresentada recentemente pelo presidente da Confederação Nacional das Indústrias - CNI, que defende uma jornada semanal de trabalho de oitenta horas, quase dobrando as atuais 44 horas previstas pela CLT); ou ainda pela intensificação do ritmo da produção, retirada, redução e limitação de acesso aos direitos previdenciários.

\section{Considerações finais}

A atual conjuntura impõe aos trabalhadores e trabalhadoras, em contexto planetário - levando-se em conta que a opressão do capital frente ao trabalho não tem sido seletiva, não tem poupado nacionalidades, nem tem aliviado frações das populações mundiais por estarem situadas em países de capitalismo tardio ou periférico - , constantes desafios. Desafia a todos a se organizar, resistir aos ataques do capital e lutar, de diversas formas, seja por meio do uso das modernas ferramentas de comunicação, a exemplo das redes sociais, ou ainda, pelos meios tradicionais, fortalecendo as lutas de classe ao lado dos trabalhadores, através da participação nos sindicatos, partidos políticos de esquerda, associações, conselhos de direitos, ocupando as ruas e disputando o Estado social, não apenas por meio dos sistemas eleitorais, mas, essencialmente, nas arenas e demais espaços de poder contra-hegemônicos ao capital. É o desafio também de denunciar cotidianamente os regimes de opressão, exploração e as estratégias político-econômicas e ideológicas que os representantes do capital, dentro ou fora do Estado social capitalista, vêm adotando para impor derrotas aos trabalhadores frente aos seus direitos e conquistas históricos, em conjunturas de crise. 
Diante desse cenário desafiador, ${ }^{11}$ aos trabalhadores brasileiros resta a luta pelos seus direitos e por uma nova ordem societária, que supere os regimes de opressão e exploração de classe; que possibilitem a busca pela união e a solidariedade entre os povos, identificando nos ataques dirigidos aos demais trabalhadores na França, Grécia, Espanha, Bolívia, Argentina, Venezuela expressões da ofensiva do capital e que nos afetam a todos; a construção coletiva de pautas em comum; a resistência contra propostas conservadoras, neoliberais, que visam tão somente a garantia da acumulação capitalista à custa do sacrifício da classe trabalhadora. Assim, é fundamentalmente através da organização e luta dos trabalhadores e trabalhadoras que será possível frear o ímpeto do capital, da financeirização da economia, da dilapidação dos direitos e das políticas sociais, da previdência pública e da apropriação do fundo público no Brasil e no mundo.

Recebido em 24/4/2017 - Aprovado em 15/10/2017

\section{Referências bibliográficas}

ANFIP. Previdência: reformar para excluir? Contribuição técnica ao debate sobre a reforma da previdência social brasileira. Brasília: Anfip/Dieese, 2017.

BEHRING, Elaine. Brasil em contra-reforma: desestruturação do Estado e perda de direitos. São Paulo: Cortez, 2003.

. Acumulação capitalista, fundo público e política social. In: BOSCHETTI, Ivanete et al. (Orgs.). Política social no capitalismo: tendências contemporâneas. São Paulo: Cortez, 2008.

BOSCHETTI, Ivanete. Assistência social e trabalho no capitalismo. São Paulo: Cortez, 2016.

11. Principalmente a partir do governo Temer, onde se aprofundam ao máximo as teses neoliberais, com intenso e multidimensionado ataque às políticas sociais, principalmente a partir das contrarreformas trabalhista e previdenciária que se encontram em curso no Brasil. 
CHESNAIS, François. As dividas ilegítimas: quando os bancos fazem mão baixa nas políticas públicas. Lisboa: Círculo de Leitores, 2012.

FONTES, Virgínia. O Brasil e o capital imperialismo: teoria e história. Rio de Janeiro: EPSJV/Editora UFRJ, 2010.

HARVEY, David. Condição pós-moderna: uma pesquisa sobre as origens da mudança cultural. 25. ed. São Paulo: Loyola, 2014a.

. O novo imperialismo. 8. ed. São Paulo: Loyola, 2014b.

MANDEL, Ernest. O capitalismo tardio. São Paulo: Nova Cultural, 1985.

. A crise do capital: os fatos e sua interpretação marxista. São Paulo: Ensaio, 1990.

MARX, Karl; ENGELS, Friedrich. O manifesto comunista.4. ed. São Paulo: Boitempo, 2005.

. O 18 de brumário de Luiz Bonaparte. São Paulo: Boitempo, 2011a.

. Grundrisse. São Paulo: Boitempo, 2011b.

. O capital: crítica da economia política. Livro I: O processo de produção do capital. São Paulo: Boitempo, 2013.

MÉSZÁROS, István. A crise estrutural do capital. 2. ed. São Paulo: Boitempo, 2011. MOTA, Ana Elizabete; AMARAL, Ângela S.; PERUZZO, Juliane F. O novo desenvolvimentismo e as políticas na América Latina. In: MOTA, Ana Elizabete et al. Desenvolvimentismo e construção de hegemonia: crescimento econômico e reprodução da desigualdade. São Paulo: Cortez, 2012.

SALVADOR, Evilásio. Fundo público e políticas sociais na crise do capitalismo. Serviço Social \& Sociedade, São Paulo, n. 104, p. 605-631, out./dez. 2010.

SILVA, Maria Lúcia Lopes da. Previdência Social no Brasil: (des)estruturação do trabalho e condições para sua universalização. São Paulo: Cortez, 2012. 